\title{
Permainan Tradisional untuk Membentuk Karakter Anak Usia Dini
}

\author{
Oki Witasari ${ }^{1}$, Novan Ardy Wiyani ${ }^{2}$ \\ ${ }^{1}$ TK Diponegoro 140 Rawalo Banyumas, ${ }^{2}$ IAIN Purwokerto
}

\begin{tabular}{|c|c|}
\hline \multicolumn{2}{|l|}{ DOI : https://doi.org/10.15642/jeced.v2i1.567 } \\
\hline Abstract (10 pt) & Article Info \\
\hline \multirow{13}{*}{$\begin{array}{l}\text { Every teacher has the knowledge and understanding of character education, } \\
\text { but not all teachers master the methods of shaping children's character. The } \\
\text { reason is the lack of creativity of teachers in shaping the character of } \\
\text { children. Traditional games can actually be used by teachers as a method of } \\
\text { shaping the character of children. This has been done by the teacher at } \\
\text { Rawalo Diponegoro Kindergarten. This study aims to describe the efforts in } \\
\text { shaping children's character with traditional games in TK Rawalo } \\
\text { Diponegoro } 140 \text {. The study was conducted with the type of phenomenological } \\
\text { research with subjects such as kindergarten heads, teachers, and children. } \\
\text { Data was collected using interviews, observations, and document studies, } \\
\text { then data analysis was carried out in three stages, namely data reduction, } \\
\text { data presentation, and verification. The results of the study describe that } \\
\text { efforts to shape children's characters with traditional games in TK Rawalo } \\
\text { Diponegoro } 140 \text { conducted through three stages. First, introduce the values } \\
\text { of goodness through traditional games. Second, giving encouragement to } \\
\text { children to realize the values of goodness when playing with traditional } \\
\text { games. Third, give instructions to children to display good behaviors when } \\
\text { playing with traditional games. In the implementation of these three stages } \\
\text { the teacher not only accompanies and teaches how to play but also becomes } \\
\text { a role model for children to do good things when playing with traditional } \\
\text { games. }\end{array}$} & Article history: \\
\hline & Received: 28042020 \\
\hline & Accepted: 05062020 \\
\hline & Published online: 15062020 \\
\hline & Keywords: \\
\hline & Children \\
\hline & $\begin{array}{l}\text { Character } \\
\text { traditional games }\end{array}$ \\
\hline & \\
\hline & \\
\hline & \\
\hline & \\
\hline & 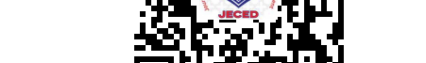 \\
\hline & \\
\hline
\end{tabular}

\begin{tabular}{l}
\hline Informasi Artikel \\
\hline Riwayat Artikel \\
Revisi terakhir: 28042020 \\
Diterima: 05062020 \\
Publikasi online: 15062020 \\
\hline Kata kunci: \\
Anak \\
Karakter \\
permainan tradisional
\end{tabular}
Data dikumpulkan menggunakan wawancara, pengamatan, dan studi dokumen, kemudian analisis data dilakukan dengan tiga tahapan, yaitu reduksi data, penyajian data, dan verifikasi. Hasil kajian mendeskripsikan bahwa upaya membentuk karakter anak dengan permainan tradisional di TK Diponegoro 140 Rawalo dilakukan melalui tiga tahap. Pertama, mengenalkan nilai-nilai kebaikan melalui permainan tradisional. Ke dua, memberikan dorongan kepada anak agar mewujudkan nilai-nilai kebaikan pada saat bermain dengan permainan tradisional. Ke tiga, memberikan petunjuk kepada anak untuk menampilkan perilaku-perilaku baik saat bermain dengan permainan tradisional. Pada pelaksanaan ketiga tahapan tersebut guru bukan sekedar mendampingi dan mengajarkan cara bermain tetapi juga menjadi role model bagi anak untuk melakukan kebaikankebaikan saat bermain dengan permainan tradisional. 


\section{PENDAHULUAN}

Pada kehidupan umat manusia, pendidikan menjadi dasar kehidupan yang fundamen. Anak sebagai subjek dalam pendidikan dapat memperoleh layanan pendidikan baik di lembaga pendidikan formal maupun lembaga pendidikan non formal. Pada kedua lembaga tersebut anak disiapkan agar bisa berkiprah di masyarakatnya pada masa sekarang dan di masa yang akan dapat (Maunah, 2009, p.5). Pengetahuan dan perilaku anak di lembaga pendidikan dididik, dibina, dan dilatih melalui proses pendidikan. Hal itu menjadikan pengetahuan dan perilaku anak mengalami perubahan. Dengan demikian, pendidikan merupakan suatu proses yang dilakukan untuk mengubah pengetahuan dan perilaku anak. Dalam proses perubahan tersebut anak akan mendapatkan banyak pengalaman belajar yang bisa memberikan kemanfaatan baginya saat ia berada di lingkungan sekolah, keluarga, dan masyarakatnya. Agar proses perubahan pengetahuan dan perilaku bisa berlangsung optimal maka pendidikan seyogyanya diberikan kepada anak sejak ia berada pada masa usia dini sampai akhir hayatnya (Novan Ardy Wiyani dan Barnawi, 2012). Pendidikan berperan penting dalam tumbuh-kembang anak sejak dini untuk membantu mengoptimalkan tumbuh-kembangnya. Ketika tumbuh kembang anak berlangsung optimal, ia akan memiliki kemampuan untuk menyelesaikan tugas-tugas kesehariannya dengan baik (Rihlah, 2019, p.9-20).

Ketika anak berada pada rentang usia nol hingga enam tahun, anak mengalami proses pertumbuhan dan perkembangan yang pesat (Novan Ardy Wiyani, 2015, p.21). Masa fase usia dini menjadi waktu yang strategis ketika memulai pembentukan karakter anak (Novan Ardy Wiyani, 2012, p.20) sehingga masa ini sering disebut dengan masa keemasan (golden age). Karakter anak terbentuk melewati tahapan-tahapan stimulasi yang didapatnya ketika menjalani kehidupan kesehariannya. Kemudian stimulus-stimulus itu diproses melalui kemampuan kognisinya lalu diaktualisasikan oleh anak pada aktivitas hariannya (Muhammad Fadlillah, 2012, p.42).

Anak usia dini sebagai pribadi yang belum dewasa memerlukan upaya pembinaan fisik dan psikis dari orang dewasa. Orang dewasa mempunyai kontribusi yang strategis pada proses pembentukan karakter anak, yaitu dengan menjadi teladan yang nyata bagi anak untuk melakukan kebaikan. Upaya membentuk karakter anak usia dini oleh orang dewasa dilakukan di lingkungan keluarga (Novan Ardy Wiyani, 2014, p.16). Upaya yang dilakukan untuk membentuk karakter anak akan lebih optimal lagi jika orang tua mampu menjalin kerjasama dengan guru di lembaga PAUD dalam upaya membentuk karakter anak. Hal ini sebagaimana dinyatakan dalam dokumen desain pengembangan karakter di sekolah bahwa penumbuhan karakter dan budi pekerti dapat dioptimalkan melalui pembelajaran yang bermakna, ekosistem, dan budaya sekolah yang sehat, guru sebagai panutan, serta membutuhkan peran lingkungan keluarga serta masyarakat (Farisia, 2018, p. 2).

Guru pada lembaga PAUD menjadi aktor utama dalam pembentukan karakter anak di lingkungan sekolah. Dengan empat kompetensinya, guru diharapkan bukan sekedar menguasai pengetahuan dan pemahaman tentang pendidikan karakter tetapi juga memiliki penguasaan terhadap strategi dalam pembentukan karakter. Namun sayangnya berdasarkan hasil wawancara dan pengamatan awal pada beberapa sekolah untuk anak usia dini di kecamatan Rawalo kabupaten Banyumas dapat diketahui bahwa semua guru sudah memiliki pengetahuan dan pemahaman tentang pendidikan karakter, tetapi belum semuanya memiliki penguasaan terhadap metode dalam pembentukan karakter anak. Pada dasarnya penyebabnya adalah karena guru masih enggan (belum memiliki inisiatif) untuk serius dalam membentuk karakter anak. Masalah terbatasnya waktu dalam mendidik anak di lembaga PAUD menjadi alasan utamanya. Selain itu ketika guru membentuk karakter anak upaya tersebut lebih banyak dilakukan dengan pemberian hafalan suratsurat dan hadist-hadist pendek, nyanyian-nyanyian serta yel-yel. Kegiatan pembiasaan pun 
dilakukan asal jalan. Para guru belum semuanya memiliki kreativitas dalam membentuk karakter anak.

Pada saat melakukan observasi pendahuluan penulis menemukan lembaga PAUD yang para gurunya memiliki inisiatif dan kreativitas dalam membentuk karakter anak melalui permainan tradisional. Lembaga PAUD tersebut adalah Diponegoro 140 Rawalo. Melalui kegiatan bermain dengan permainan tradisional anak dapat belajar tentang kebaikan. Pengetahuan tentang kebaikan itu kemudian dijadikan sebagai modal bagi anak untuk mampu melakukan kebaikan tersebut. Upaya guru pada TK Diponegoro 140 Rawalo ketika membentuk karakter anak usia dini dengan permainan tradisional sudah berlangsung selama tiga tahun, dari tahun pelajaran 2016/2017 sampai 2018/2019.

Temuan penulis di TK Diponegoro 140 Rawalo telah mendorong penulis guna melaksanakan kajian tentang upaya membentuk karakter anak dengan permainan tradisional di TK tersebut. Dengan demikian penelitian ini ditujukan untuk mendapatkan deskripsi tentang pembentukan karakter pada anak usia dini melalui permainan tradisional di TK Diponegoro 140 Rawalo. Hasil dari kajian ini dapat dijadikan sebagai guideline bagi lembaga PAUD yang lain dalam upaya membentuk karakter anak usia dini melalui permainan tradisional. Diakui ataupun tidak saat ini masih ada lembaga PAUD yang belum memiliki kemauan dan kemampuan untuk membentuk karakter anak dengan memanfaatkan berbagai permainan tradisional.

\section{METODE}

Pendekatan penelitian yang digunakan dalam kajian ini adalah pendekatan penelitian kualitatif dengan jenis penelitian fenomenologi. Penulis melakukan eksplorasi terhadap lembaga PAUD yang memiliki kemampuan lebih dalam membentuk karakter anak usia dini dengan permainan tradisional di kecamatan Rawalo kabupaten Banyumas. Lembaga PAUD tersebut adalah TK Diponegoro 140 Rawalo yang beralamat di Jalan Rawacangkring RT 02 RW 08 desa Rawalo kecamatan Rawalo kabupaten Banyumas. Beberapa hal yang menjadikan penulis melaksanakan kajian di lembaga pendidikan tersebut antara lain: (1) masih minimnya lembaga PAUD yang menggunakan permainan tradisional; permainan tradisional untuk membentuk karakter anak di lembaga PAUD tersebut telah dilakukan oleh guru lebih dari tiga tahun secara berturut-turut; (3) anak telah memiliki kemampuan untuk melakukan kebaikan-kebaikan ketika bermain di lembaga PAUD.

Sumber data pada penelitian ini yaitu kepala TK dan guru serta peserta didik di TK Diponegoro 140 Rawalo. Interview, pengamatan, dan studi dokumen digunakan oleh penulis sebagai teknik pengumpulan data. Setelah itu penulis menganalisis data menggunakan teknik analisis data versi Miles dan Huberman yaitu melalui proses data reduction, data display, dan verivication. Untuk menghasilkan data yang valid dan kredibel digunakanlah uji validitas dengan teknik triangulasi. Triangulasi adalah pengecekan data dari berbagai sumber dengan berbagai cara dan waktu (Farisia, 2017, p. 8). Adapun teknik triangulasi yang digunakan dalam penelitian ini adalah triangulasi sumber dengan cara telaah dan kros check data hasil wawancara dengan data dokumen.

\section{HASIL PENELITIAN DAN ANALISIS}

Ada tiga tahapan yang dilakukan oleh guru di TK Diponegoro 140 Rawalo dalam menggunakan permainan tradisional sebagai upaya membentuk karakter anak. Tahap pertama adalah mengenalkan kepada anak tentang nilai-nilai kebaikan yang terkandung dalam permainan tradisional. Pada tahap pertama ini ada tiga upaya yang dilakukan oleh guru. Pertama, mengenalkan nilai-nilai kebaikan melalui permainan tradisional. Pembentukan karakter anak diawali dengan mengenalkan nilai-nilai kebaikan yang mudah dipahami oleh anak. Guru menjelaskan kepada anak tentang contoh-contoh perilaku baik dan perilaku buruk ketika mereka 
bermain. Perilaku baik yang dicontohkan saat bermain seperti saling tolong-menolong, jujur, mau menerima kekalahan, sportif, dan pemaaf. Kemudian perilaku buruk yang ditunjukkan seperti berkelahi karena kalah, melukai teman saat bermain, bermain curang, dan melanggar aturan bermain. Upaya itu dilakukan ketika anak bermain dengan permainan tradisional. Guru menyampaikannya dengan menggunakan metode bercerita sebelum anak-anak bermain serta dengan metode nasehat ketika anak bermain. Penggunaan metode nasehat lebih banyak digunakan secara spontan ketika ada anak yang menampilkan perilaku-perilaku yang positif dan negatif.

Kedua, menjelaskan tentang kebermanfaatan dari perilaku yang sesuai dengan nilai-nilai kebaikan saat bermain dengan permainan tradisional. Tujuannya yaitu agar anak menjadi tahu dan bisa memahami kebermanfaatan yang didapat dari perbuatan baiknya. Harapannya agar anak bisa menerapkan perbuatan baiknya di lingkungan sekolah, keluarga, dan masyarakat. Anak dapat memahami manfaat dari mengaplikasikan nilai-nilai kebaikan sehingga mendorong anak untuk berperilaku baik. Perilaku baik tersebut seperti ketika ia mau berbagi sesuatu saat bermain permainan tradisonal, menolong temannya saat bermain, tidak berlaku curang, mau menerima kekalahan dengan lapang dada, dan lain sebagainya. Ketiga, mengungkapkan akibat ketika melakukan keburukan saat bermain dengan permainan tradisional. Anak mampu memahami suatu aktivitas di saat ia terlibat dalam aktivitas tersebut. Jadi guru dapat mengungkapkan akibat ketika anak melakukan keburukan dengan memberikan penjelasan tentang dampak keburukan yang dia lakukan bagi sesamanya melalui kejadian-kejadian yang riil di lingkungannya. Misalnya ketika anak bermain curang dengan temannya saat bermain akibatnya anak tidak akan diajak bermain lagi oleh teman-temannya. Upaya itu dilakukan oleh guru TK Diponegoro 140 Rawalo ketika mendampingi anak bermain dengan permainan tradisional. Pada kegiatan ini guru menggunakan metode nasehat.

Tahap kedua adalah memberikan dorongan kepada anak agar mewujudkan nilai-nilai kebaikan pada saat bermain dengan permainan tradisional. Pada tahap ini ada tiga upaya yang dilakukan oleh guru. Pertama, mengenalkan aturan bermain, cara bermain dan manfaat permainan tradisional pada anak. Hal ini dilakukan agar tumbuh minat pada diri anak untuk bermain dengan permainan tradisional. Upaya ini dilakukan oleh guru dengan metode demonstrasi dan metode bercerita. Kedua, mengungkapkan kisah-kisah populer di masyarakat yang mendeskripsikan tentang kebaikan-kebaikan manusia dalam berinteraksi sosial setelah anak bermain atau ketika anak beristirahat dari kegiatan bermain. Ketiga, memberikan hadiah dan hukuman atas perilaku yang ditampilkan oleh anak ketika bermain dengan permainan tradisional. Hadiah yang diberikan seperti pemberian pujian, pemberian simbol bintang, pemberian pelukan dan pemberian makanan tradisional kepada anak yang berperilaku positif. Sedangkan hukuman yang diberikan berupa pemberian teguran.

Tahap ketiga adalah memberikan petunjuk kepada anak untuk menampilkan perilakuperilaku baik saat bermain dengan permainan tradisional. Ada tiga upaya yang dilakukan oleh guru pada tahap yang ketiga ini. Pertama, memberikan contoh perilaku baik kepada anak ketika bermain dengan permainan tradisional. Ketika anak diberi contoh secara langsung, anak akan mengamati kemudian dapat memahami hal-hal yang dideskripsikan oleh gurunya. Anak juga lebih mudah menirunya dalam kehidupan sehari-hari. Pemberian contoh perilaku baik juga mendorong anak antusias untuk bermain. Kedua, melibatkan anak berbuat baik ketika bermain dengan permainan tradisional. Memberikan contoh saja belum tentu anak paham. Setelah memberikan contoh guru harus menindaklanjutinya dengan memberikan instruksi kepada anak untuk melakukan kebaikan-kebaikan. Misalnya menegur anak yang melanggar aturan kemudian meminta anak untuk bermain dengan sportif, menjelaskan kepada anak jika ia mau meminta tolong kepada anak lainnya untuk mengambilkan alat bermain maka permintaan tolong tersebut dilakukan dengan santun, dan lain sebagainya. Ketiga, membiasakan anak untuk mengaktualisasikan nilai-nilai kebaikan dalam permainan tradisional. Pembiasaan sangat penting 
dan tepat untuk membentuk karakter anak usia dini, dengan terbiasa berbuat baik maka ia akan melakukan pengulangan terhadap kebaikan-kebaikan tersebut. Misalnya membiasakan anak untuk berdoa pada kegiatan pra-bermain dan pasca-bermain bermain, ketika bermain anak dibiasakan untuk menghargai teman dan bersikap sportif, anak dibiasakan memohon maaf atas kesalahan saat bermain, anak dibiasakan memohon pertolongan saat bermain, anak dibiasakan menyampaikan terima kasih saat dibantu, dan lain sebagainya.

Berdasarkan hasil interview dan observasi berikut penulis sajikan jenis-jenis permainan tradisional yang digunakan untuk membentuk karakter anak di TK Diponegoro 140 Rawalo:

Tabel 1. Uraian Nilai-nilai Karakter pada Permainan Tradisional

\begin{tabular}{ccc}
\hline No & $\begin{array}{c}\text { Nama Permainan } \\
\text { Tradisional }\end{array}$ & Uraian Nilai Karakter \\
\hline 1. & Bola bekel & Permainan bola bekel dilaksanakan secara individu dalam satu
\end{tabular}
kelompok. Anak-anak bermain secara bergiliran berdasarkan aturan yang telah ditetapkan oleh guru. Pada permainan ini anak menunjukkan karakter tanggungjawab saat membereskan peralatan yang digunakan. Kedisiplinan anak juga terlihat ketika mereka mau bermain sesuai dengan aturan. Sementara itu sikap komunikatif ditunjukkan oleh anak saat menjalin komunikasi dengan sesama. Kemampuan anak untuk menerima kekalahan juga telah menunjukkan bahwa anak memiliki karakter lapang dada dan cinta damai.

2. Lompat Tali Permainan lompat tali dilakukan secara individu dalam satu kelompok. Anak-anak mematuhi setiap aturan bermain dan ini menunjukkan anak memiliki karakter disiplin. Kemauan anak untuk membenahi alat yang digunakan untuk bermain juga menunjukkan anak memiliki karakter tanggungjawab. Penerimaan anak terhadap kekalahannya telah menunjukkan anak berlapang dada dan cinta damai. Kemampuan anak untuk saling berinteraksi saat bermain membuatnya memiliki kemampuan untuk berkomunikasi. Pada dasarnya anak ketika bermain dengan permainan tradisional akan terpupuk rasa cinta terhadap tanah airnya.

3. Yoyo Permainan yoyo dimainkan oleh anak secara individu. Banyak anak yang belum bisa bermain yoyo tetapi mereka tetap berusaha kerja memainkannya. Anak mau belajar bermain yoyo. Ini menunjukkan bahwa mereka memiliki karakter kerja keras. Ketika anak gemar bermain yoyo maka akan tertanam rasa cinta pada budayanya.

4. Gatrik Permainan gatrik dilakukan secara individu dalam satu kelompok. Anak-anak mematuhi semua aturan yang ada. Ini menunjukkan mereka mampu berdisplin saat bermain. Mereka satu sama lain saling berinteraksi dan ini membuatnya memiliki kemampuan dalam berkomunikasi. Anak juga mau menerima kekalahan saat bermain dan ini menunjukkan bahwa anak berkarakter cinta damai. Kemudian ketika anak gemar bermain gatrik maka artinya telah tertanam akan cinta pada tanah air dalam diri anak.

\begin{tabular}{ll}
\hline $5 . \quad$ Hompimpa & $\begin{array}{l}\text { Hompimpa merupakan permainan yang dilakukan secara } \\
\text { kolaboratif. Ketika anak bermain sesuai dengan aturan itu artinya }\end{array}$ \\
\hline
\end{tabular}


anak sudah mampu untuk bersikap disiplin. Saat anak mau menerima kekalahan itu artinya anak memiliki karakter lapang dada dan cinta damai. Ketika anak mau mengakui kekalahannya dan kemenangan anak lain maka ia telah menjadi pribadi yang jujur. Pada permainan ini sikap komunikatif pada anak juga dapat terbentuk. Ini karena di dalam permainan tradisional hompimpa syarat akan interaksi antar pemain.

6. Ular Naga Permainan ular naga dilakukan secara kolaboratif. Ketika anakanak mematuhi aturan main itu artinya anak sudah mampu bersikap disiplin. Kemampuan anak dalam menjalin relasi saat bermain juga menunjukkan bahwa anak memiliki sikap komunikatif. Sedangkan ketika anak mau menerima kekalahan dan tidak saling berkelahi saat kalah menunjukkan jika anak cinta damai. Pengakuan tersebut juga menunjukkan anak menjadi pribadi yang jujur. Keuletan anak saat bermain menunjukkan bahwa ia memiliki karakter kerja keras. Kemudian kegemaran anak dalam bermain ular tanggal telah menunjukkan bahwa mereka cinta tanah airnya.

7. Pancasila Lima Permainan ini dilakukan secara berkelompok. Anak-anak bermain Dasar sesuai dengan aturan dan ini menunjukkan bahwa mereka sudah mampu bersikap disiplin saat bermain. Anak juga mampu bersabar menunggu anak lainnya berfikir untuk menyebutkan nama-nama buah yang diawali dengan huruf vokal. Kemampuan anak untuk bermain sesuai aturan dan tidak curang menjadikannya memiliki karakter jujur. Sementara itu keberaniannya dalam mengakui serta menerima kekalahan menunjukkan ia menjadi pribadi yang cinta damai. Sedangkan ketelatenan anak saat bermain menunjukkan jika anak memiliki karakter kerja keras. Sikap komunikatif anak saat bermain juga ikut terbentuk karena permainan ini mengharuskan antara anak yang satu dengan yang lainnya untuk saling berkomunikasi. Kegemaran anak dalam melakukan permainan ini menunjukkan jika anak memiliki karakter cita tanah air.

8. Kelereng Permainan kelereng dilakukan secara individual di dalam suatu kelompok. Permainan ini bersifat kompetitif. Anak-anak yang bermain sesuai dengan aturan dan tidak curang pada permainan ini menunjukkan bahwa mereka memiliki karakter cinta damai dan jujur. Bermain kelereng bukanlah hal yang mudah. Diperlukan konsentrasi untuk mendapatkan bidikan yang tepat. Hal ini membuat anak-anak slalu bekerja keras saat bermain. Selesai bermain kelereng anak-anak tidak segan untuk merapihkan kembali peralatan yang digunakan untuk bermain dan ini merupakan wujud dari pertanggungjawaban anak-anak setelah bermain. Tentunya ketika anak mau bermain dan memiliki kegemaran bermain kelereng ini berarti mereka memiliki rasa cinta terhadap budayanya.

9. Benteng Pada saat bermain benteng anak-anak memulainya dengan berdoa. Ini menunjukkan ditanamkan karakter religius pada permainan ini. Antara anak yang satu dengan yang lainnya juga 
aktivitas berinteraksi sehingga kemampuan mereka dalam berkomunikasi semakin terasah. Kemudian kepatuhan anak pada peraturan dalam bermain juga menunjukkan kedisiplinannya. Sementara itu keberanian anak untuk mengakui kekalahannya sendiri saat bermain menunjukkan bahwa anak telah menjadi pribadi yang jujur dan cinta damai.

10. Boy-boyan Permainan ini merupakan permainan kolaboratif. Anak-anak bermain sangat disiplin dengan senantiasa mematuhi setiap aturan permainan. Ketika ada seorang anak yang terkena lemparan bola ia pun tidak segan mengakui kekalahannya. Ia telah berlaku jujur terhadap dirinya dan orang lain. Permainan boy-boyan menuntut agar anak mampu bekerja keras dalam bermain. Selain itu permainan boy-boyan juga mengajarkan kebersamaan yang bisa memunculkan sikap peduli pada anak.

11. Petak Umpet Permainan ini merupakan permainan yang paling populer dibandingkan dengan permainan tradisional lainnya. Pada permainan ini anak diajarkan untuk jujur ketika tertangkap saat bermain. Berani mengakui kekalahan. Disiplin saat bermain dengan mematuhi aturan serta saling peduli satu sama lain ketika melihat temannya terjatuh saat berlari.

12. Congklak Congklak merupakan jenis permainan kompetitif. Anak yang bermain sesuai dengan aturan dan tidak curang berarti telah memiliki karakter jujur dan sportif. Anak juga diajari untuk bersabar dalam permainan ini, yaitu sabar dalam menunggu giliran. Anak juga diajarkan untuk telaten dan bekerja keras saat bermain. Setelah bermain anak merapikan alat bermainnya dan ini menunjukkan mereka memiliki karakter tanggungjawab.

13. Engklek Engklek merupakan permainan tradisional yang digemari oleh anak. Ketika anak gemar melakukan permainan ini maka artinya ada karakter cinta tanah air pada diri anak. Anak dalam permainan ini diajarkan untuk berkonsentrasi dan untuk mampu menjaga keseimbangan tubuhnya. Ini menjadikan anak belajar untuk hidup ulet dan memiliki sikap gemar bekerja keras.

14. Tikus dan Kucing Permainan tikus dan kucing dilakukan secara berkelompok. Anak-anak diajari untuk kompak dalam bermain. Hal ini membuat anak belajar tentang kebersamaan dan kepedulian. Permainan ini juga menjadikan kemampuan anak untuk berkomunikasi semakin berkembang. Kepatuhan anak pada aturan membuat pelaksanaan kegiatan bermain kondusif. Anak diajarkan untuk bersikap disiplin dan patuh pada aturan.

15. Suten Permainan suten seringkali dimainkan oleh anak untuk mendapatkan giliran bermain pada satu permainan. Dengan suten anak diajari untuk bersikap sportif, jujur, dan berlapang dada. Pada dasarnya ketika anak gemar bermain suten maka berarti mereka memiliki karakter cinta terhadap budayanya. Permainan suten dilakukan secara bergiliran dan ini membuat anak-anak mau belajar untuk bersabar. 
Semua kegiatan bermain dengan permainan tradisional di TK Diponegoro 140 Rawalo dilaksanakan secara kolaboratif. Aktivitas tersebut menjadikan anak memiliki kemauan dan kemampuan untuk saling bekerjasama saat bermain. Ketika itu bisa dilakukan maka akan terbentuk sikap prososial pada diri anak (Hewi \& Surpida, 2019, p.115-128). Selain itu permainan tradisional yang dilakukan oleh anak juga dapat menumbuhkan kepekaan pada diri anak terhadap dirinya dan lingkungan sekitarnya. Hal itu akan berimplikasi pada perkembangan emosi anak yang optimal (Ramadhan Lubis dan Khadijah, 2018).

Berikut adalah sampel gambar kegiatan bermain dengan permainan tradisional yang digunakan sebagai strategi untuk membentuk karakter anak di TK Diponegoro 140 Rawalo:

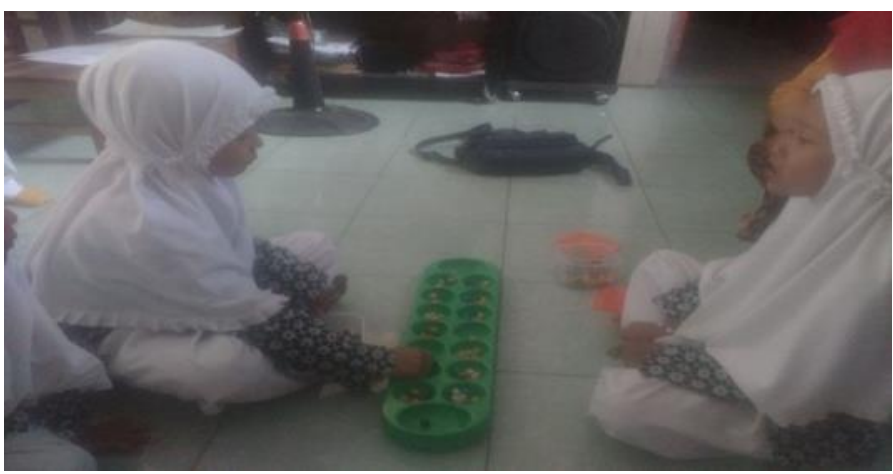

Gambar 1. Anak Sedang Bermain Congklak

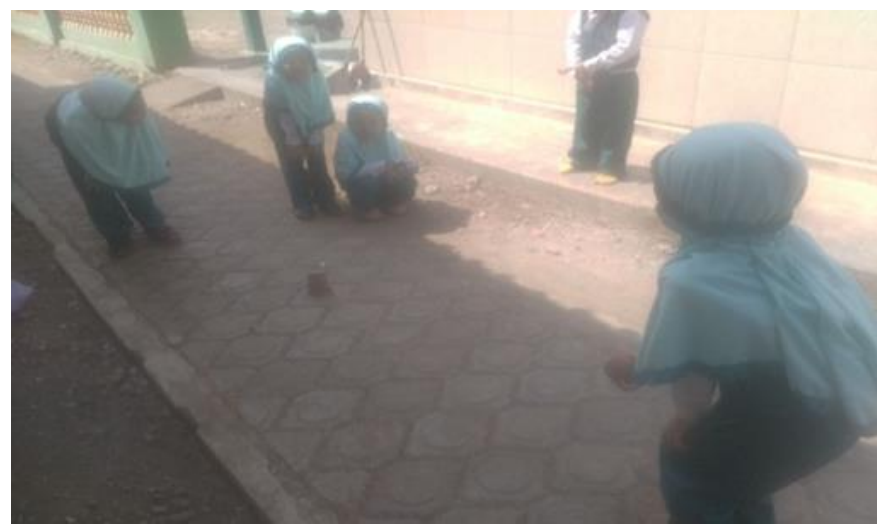

Gambar 2. Anak Sedang Bermain Boy-boyan

Berdasarkan hasil penelitian dapat diketahui bahwa ada tiga faktor pendukung ketika guru membentuk karakter anak dengan permainan tradisional di TK Diponegoro 140 Rawalo. Pertama, adanya pemberian alokasi waktu khusus bagi guru dan anak oleh kepala TK dalam melaksanakan kegiatan bermain dengan permainan tradisional. Kepala TK pun memberikan kepercayaan penuh kepada guru untuk melaksanakan kegiatan tersebut. Waktu kegiatan bermain adalah sebelum anakanak masuk dalam kegiatan inti pada pembelajaran PAUD. Kedua, adanya antusiasme dari anak ketika mengikuti kegiatan bermain dengan permainan tradisional. Antusiasme tersebut muncul karena dalam kesehariannya anak sangat jarang bermain dengan permainan tradisional. Anak lebih banyak bermain menggunakan gadget. Ketiga, guru tidak enggan untuk terlibat aktif ketika bermain dengan permainan tradisional. Pada saat itu guru bisa menjadi role model bagi anak agar mereka mampu melakukan kegiatan bermain dengan permainan tradisional sesuai dengan aturan.

Sementara itu ada tiga faktor penghambat ketika membentuk karakter anak dengan permainan tradisional di TK Diponegoro 140 Rawalo. Pertama, orangtua belum seluruhnya mau dan mampu mengajak anak untuk bermain dengan permainan tradisional di lingkungan keluarga maupun di lingkungan masyarakat. Kedua, keterbatasan luas halaman TK sehingga tidak semua 
kegiatan bermain dengan permainan tradisional bisa dilakukan secara leluasa. Keterbatasan area bermain di suatu lembaga PAUD dapat mempengaruhi kelancaran kegiatan bermain yang dilakukan oleh anak. Daya gerak anak menjadi terbatas, akhirnya hasil yang didapat dari kegiatan bermain pun menjadi terbatas (Pancaningrum, 2018). Ketiga, peralihan dari kegiatan bermain dengan permainan tradisional ke kegiatan inti dalam pembelajaran PAUD seringkali kurang kondusif karena ada beberapa anak yang mengalami kelelahan.

\section{PEMBAHASAN}

Pendidikan karakter pada dasarnya merupakan proses transformasi ataupun internalisasi nilai karakter ke dalam diri anak. Nilai karakter bisa juga diistilahkan dengan nilai kebaikan. Proses transformasi maupun internalisasik bisa dilakukan melalui kegiatan pembelajaran, pembiasaan, dan ekstrakurikuler. Anak yang belajar pada jenjang PAUD memiliki perbedaan dengan anak yang belajar pada jenjang dikdasmen, seperti SD dan MI. Anak di lembaga PAUD mengikuti kegiatan pembelajaran dengan cara bermain. Pada saat anak bermain berbagai aspek tumbuh-kembangnya ikut terlibat (Anggraini \& Putri, 2019). Hal itu internalisasi nilai karakter dapat dilakukan melalui kegiatan bermain. Ada banyaka jenis kegiatan bermain yang bisa dilakukan oleh anak dan bisa digunakan sebagai media untuk menginternalisasikan nilai karakter. TK Diponegoro 140 Rawalo memilih permainan tradisional sebagai jenis kegiatan bermain guna untuk mengoptimalkan pembentukan karakter anak. Pemilihan permainan tradisional di TK Diponegoro 140 Rawalo sangatlah strategis. Bukan hanya karakter pada anak usia dini saja yang terbentuk tetapi juga eksistensi permainan tradisional dapat lestari. Berbagai permainan tradisional di suatu daerah pada dasarnya merupakan suatu bentuk kearifan lokal yang harus dikenalkan kepada anak melalui kegiatan pembelajaran (Pamungkas dkk., 2019).

Nilai karakter yang diinternalisasikan pada anak pada aktivitas bermain dengan permainan tradisional antara lain disiplin, kerja keras, jujur, cinta damai, cinta tanah air, komunikatif, dan tanggung jawab. Ketika nilai karakter tersebut bisa diaktualisasikan oleh anak usia dini saat bermain dengan permainan tradisional, ekspektasinya setiap anak usia dini juga bisa mengaktualisasikannya dalam kehidupan sehari-hari baik pada lingkup TK maupun di rumahnya dan dan di lingkungan masyarakat.

Pembentukan karakter pada anak usia dini dengan kegiatan bermain memanfaatkan permainan tradisional di TK Diponegoro 140 Rawalo dilakukan dengan tiga tahapan. Pertama, mengenalkan kepada anak mengenai nilai-nilai kebaikan yang terkandung dalam permainan tradisional. Kedua, memberikan dorongan kepada anak agar mewujudkan nilai-nilai kebaikan pada saat bermain dengan permainan tradisional. Ketiga, memberikan petunjuk kepada anak untuk menampilkan perilaku-perilaku baik saat bermain dengan permainan tradisional.

Pengenalan kepada anak mengenai nilai-nilai kebaikan disebut dengan istilah knowing the good. Ini merupakan langkah awal yang dilakukan oleh guru ketika membentuk karakter anak. Pada dasarnya tujuan dari dilakukannya pemberian pengetahuan tentang nilai-nilai kebaikan adalah untuk mengenalkan berbagai perbuatan yang positif serta berbagai perbuatan yang negatif pada anak usia dini. Disadari ataupun tidak, anak usia dini masih mengalami kesulitan ketika mengidentifikasi perbedaan antara perilaku positif dengan perolaku negatif. Tugas orang dewasa seperti guru adalah menunjukkan kepada anak mana saja bentuk-bentuk perilaku tersebut. Hal itu bisa dilakukan oleh guru kepada anak ketika anak bermain dengan permainan tradisional. Pengenalan aturan bermain dan pemberian contoh bermain yang baik dapat dijadikan sebagai strategi untuk menunjukkan contoh perilaku yang positif dan perilaku negatif pada anak.

Kemudian memberikan dorongan kepada anak agar mewujudkan nilai-nilai kebaikan pada saat bermain dengan permainan tradisional bisa diupayakan oleh guru dengan menunjukkan kemanfaatan dari nilai-nilai kebaikan yang diaktualisasikan oleh anak saat bermain dengan permainan tradisional, maupun ketika anak tinggal di rumah dan lingkungannya. Selain itu guru 
juga menunjukkan kepada anak mengenai mudharat perbuatan negatif yang diperbuat anak baik terhadap dirinya maupun terhadap sesamanya. Tugas guru di sini idealnya adalah memberikan bimbingan kepada anak agar anak selalu memposisikan diri untuk melakukan kebaikan-kebaikan. Ketika hal itu dapat dilakukan oleh anak maka ia menjadi sosok pecinta kebaikan atau loving the good.

Pengetahuan akan kebaikan (knowing the good) dan kecintaan pada berbagai hal yang baik (loving the good) pada diri anak dapat menggerakkannya berperilaku baik di dalam kehidupan sehari-harinya (acting the good). Jadi tugas guru selanjutnya adalah mengarahkan agar anak mau serta mampu melakukan kebaikan. Itulah sebabnya pada tahap ketiga guru melakukan pemberian memberikan petunjuk kepada anak untuk menampilkan perilaku-perilaku baik saat bermain dengan permainan tradisional. Petunjuk diberikan secara optimal melalui keteladanan. Dalam hal ini guru terlibat secara langsung dalam kegiatan bermain dengan permainan tradisional. Guru memberikan contoh tentang bagaimana cara bermain sesuai dengan aturan dan cara memperlakukan teman saat bermain. Dengan demikian dalam pembentukan karakter anak melalui permainan tradisional guru harus mampu memposisikan diri sebagai role model atau teladan bagi anak-anak. Kehadiran guru ketika anak bermain bukan sekedar melihat, tetapi ikut mendampingi dengan memberikan contoh serta mengontrol perilaku anak, baik itu perilaku positif maupun perilaku yang negatif. Pemberian pendampingan kepada anak saat bermain akan dapat memacu antusiasme dan keterlibatan anak saat bermain (Hunainah, 2019).

Kemudian jika guru bisa memberikan hadiah kepada anak dengan harapan agar anak konsisten untuk melakukan kebaikan. Hadiah yang diberikan bisa berupa pujian, ucapan selamat, dan pemberian simbol bintang atau simbol lainnya. Berdasarkan hasil penelitian disebutkan bahwa penggunaan simbol bintang dapat memunculkan kepercayaan diri pada anak ketika melakukan sesuatu (Munawaroh, 2019). Pemberian hadiah juga harus dibarengi dengan pemberian hukuman. Hukuman bisa berupa teguran dan pemberian sanksi. Tujuannya adalah untuk mencegah agar anak tidak berperilaku buruk (Jajang Aisyul Muzakki, 2016).

Tentunya dalam pelaksanaan suatu kegiatan ataupun program ada faktor pendukung dan faktor penghambatnya. Faktor pendukung ketika membentuk karakter anak dengan permainan tradisional di TK Diponegoro 140 Rawalo harus dipertahankan bahkan dikembangkan agar ada faktor-faktor pendukung yang lainnya. Untuk itu kepala TK sebagai seorang pemimpin sekaligus manajer perlu membuat kebijakan secara formal tentang penerapan permainan tradisional di TK Diponegoro 140 Rawalo. Kebijakan tersebut nantinya dapat dijadikan sebagai bahan pertimbangan oleh guru dalam menyusun kurikulum PAUD. Jadi nanti akan dihasilkan kurikulum PAUD di TK Diponegoro 140 Rawalo yang mendukung pelaksanaan kegiatan bermain dengan permainan tradisional. Keberhasilan pada pelaksanaan suatu program atau kegiatan termasuk pembentukan karakter pada melalui permainan tradisional sangat ditentukan oleh gaya kepemimpinan kepala TK. Agar kepala TK mampu bekerjasama bukan hanya dengan guru maupun dengan orangtua dan komite sekolah maka ia harus memiliki kemampuan untuk mengaktualisasikan gaya kepemimpinan demokratis (Wahyuni, 2019).

\section{SIMPULAN DAN SARAN}

Upaya memanfaatkan permainan tradisional untuk membentuk karakter anak di TK Diponegoro 140 Rawalo telah dilaksanakan secara sistematis dan hasilnya anak-anak mampu menampilkan karakter positif ketika melakukan kegiatan bermain dengan permainan tradisional. Keberhasilan tersebut karena tiga tahap yang dilakukan dalam kegiatan bermain untuk membentuk karakter anak dilakukan dengan diiringi pemberian pendampingan dan pemberian keteladanan oleh guru. Anak mau dan mampu terlibat aktif untuk berbuat baik saat bermain ketika didampingi oleh guru dengan optimal dan diberi berbagai contoh perilaku positif oleh guru saat bermain bersama. 
Ada empat saran yang penulis ajukan berdasarkan hasil penelitian ini. Pertama, kepala TK Diponegoro 140 Rawalo sebagai seorang pemimpin harus konsisten dalam memberikan teladan yang baik bagi guru dan peserta didik. Kedua, guru diharapkan dapat menumbuhkan dan menciptakan interaksi yang baik dalam pembelajaran agar terciptanya suasana yang kondusif sehingga peserta didik dapat memahami pesan apa yang disampaikan oleh dengan baik saat kegiatan bermain dengan permainan tradisional berlangsung. Ketiga, wali murid seyogyanya memiliki kesadaran bahwa pembentukan karakter tidak hanya dilakukan di lembaga PAUD tetapi juga di lingkungan keluarga. Jadi tidak ada salahnya jika orangtua bermain permainan tradisional bersama dengan anak. Keempat, peneliti lain yang hendak meneliti tentang permainan tradisional sebagai media untuk membentuk karakter anak lebih baik memfokuskan penelitiannya pada satu bentuk permainan saja agar didapat hasil penelitian yang mendalam.

\section{AKNOWLEDGMENT}

Penelitian ini didukung oleh Kementerian Agama (Kemenag) Republik Indonesia (RI), IAIN Purwokerto dan TK Diponegoro 140 Rawalo kecamatan Rawalo kabupaten Banyumas propinsi Jawa Tengah.

\section{DAFTAR RUJUKAN}

Anggraini, W., \& Putri, A. D. (2019). Penerapan Metode Bermain Peran (Role Playing) dalam Mengembangkan Kognitif Anak Usia 5-6 Tahun. JECED : Journal of Early Childhood Education and Development, 1(2), 104-114. https://doi.org/10.15642/jeced.v1i2.466

Binti Maunah. (2009). Landasan Pendidikan. Teras.

Farisia, Hernik. (2017). Strategi Optimalisasi Kemampuan Belajar Anak Berkebutuhan Khusus (ABK) melalui Program Pembelajaran Individual. SELING; Jurnal Program Studi PGRA, $3(2), 1-17$.

Farisia, Hernik. (2018). Jurnal Handayani. Jurnal Handayani, 8(1), 1-10. https://doi.org/10.24114/jh.v8i1.10561

Hewi, L., \& Surpida, S. (2019). Permainan Dadu pada Pengembangan Perilaku Prososial Anak di

RA An-Nur Kota Kendari. JECED: Journal of Early Childhood Education and Development, 1(2), 115-128. https://doi.org/10.15642/jeced.v1i2.468

Hunainah. (2019). Pendampingan Guru TK dalam Pengembangan Metode Pembelajaran Anak

Usia Dini. Jurnal Thufula IAIN Kudus, 7(2), 273-294.

https://doi.org/10.21043/thufula.v7i2.5818

Jajang Aisyul Muzakki. (2016). MODEL PEMBERIAN HUKUMAN DALAM PENDIDIKAN

ISLAM. 2(2), 1-12. https://doi.org/10.24235/awlady.v2i2.821

Muhammad Fadlillah. (2012). Desain Pembelajaran PAUD. Ar-Ruzz Media.

Munawaroh, Z. A. (2019). Pengaruh Pemberian Reward Stiker Bintang Terhadap Percaya Diri

Anak Kelompok B di TK Thoriqussalam Sidoarjo. JECED : Journal of Early Childhood

Education and Development, 1(1), 21-29. https://doi.org/10.15642/jeced.v1i1.494

Novan Ardy Wiyani. (2012). Bina Karakter Anak Usia Dini. Ar-Ruzz Media.

Novan Ardy Wiyani. (2014). Buku Ajar Penanganan Anak Usia Dini Berkebutuhan Khusus. Ar-

Ruzz Media.

Novan Ardy Wiyani. (2015). Manajemen PAUD Bermutu: Konsep dan Praktik MMT di KB.

Gavamedia.

Novan Ardy Wiyani dan Barnawi. (2012). Format PAUD. Ar-Ruzz Media. 
Pamungkas, J., Syamsudin, A., Harun, H., \& Sudaryanti, S. (2019). Survei Pembelajaran Kearifan Lokal di Taman Kanak-Kanak Se-Provinsi Daerah Istimewa Yogyakarta. AL-ATHFAL:

JURNAL PENDIDIKAN ANAK, 5(1), 1-20. https://doi.org/10.14421/al-athfal.2019.51-01

Pancaningrum, N. (2018). PEMANFAATAN SARANA PRASARANA INDOOR DAN OUTDOOR RAUDHATUL ATHFAL. ThufuLA: Jurnal Inovasi Pendidikan Guru Raudhatul Athfal, 6(2), 344. https://doi.org/10.21043/thufula.v6i2.5229

Ramadhan Lubis dan Khadijah. (2018). Permainan Tradisional sebagai Pengembangan Kecerdasan Emosi Anak. Jurnal al Athfal UIN Sunan Kalijaga Yogyakarta, 4(2), 177-186. https://doi.org/10.14421/al-athfal.2018.42-05

Wahyuni, S. (2019). Model Kepemimpinan Lembaga PAUD kelas Menengah Berbasis Fullday School. JECED : Journal of Early Childhood Education and Development, 1(2), 67-83. https://doi.org/10.15642/jeced.v1i2.455

\section{AUTHOR}

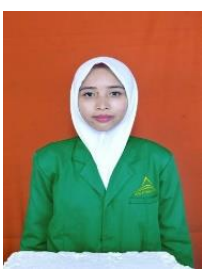

Oki Witasari Lahir di Banyumas 21 Oktober 1995. Penulis tinggal di Dusun 1 RT 02/RW 01 kecamatan Rawalo kabupaten Banyumas. Alamat email: okiwitasary21\&gmail.com. Setelah menamatkan studi S1 pada program studi PIAUD di IAIN Purwokerto. Kemudian penulis menjadi guru di TK Diponegoro 140 Rawalo, tempat di mana penulis melakukan penelitian untuk menyusun skripsi.

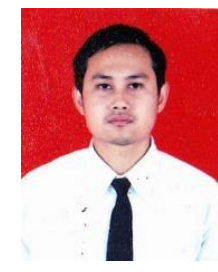

Novan Ardy Wiyani. Lahir di Brebes 25 Mei 1985. Penulis tinggal di desa Beji RT 01/RW 03 kecamatan Kedungbanteng kabupaten Banyumas. Saat ini penulis berprofesi sebagai dosen di IAIN Purwokerto. Alamat e-mail: fenomenajiwa@gmail.com. Rekam jejak dalam kepenulisan karya tulis ilmiah dapat ditelusuri pada laman https://scholar.google.co.id/citations?user=IYsxegIAAAAJ\&hl=en 